\title{
Performance of Summer Sesame under Different Irrigation Scheduling and Nutrient Levels in Vidarbha Region
}

\author{
V.A. Khadse*, P.U. Ghatol and V.M. Bhale \\ Department of Agronomy, Dr. Panjabrao Deshmukh Krishi Vidyapeeth, \\ Akola- 444104, Maharashtra, India \\ *Corresponding author
}

A B S T R A C T

Keywords

Summer Sesame, $\mathrm{RDF}$, IW/CPE,

Irrigation scheduling,

Sulphur, Yield.

Article Info

Accepted:

17 September 2017

Available Online:

10 November 2017
A field study targeted to advance effectual irrigation schedule with nutrient levels for elevated yield of summer sesame var. AKT 101, was conducted during 2012 and 2013 at Agronomy Farm, Dr. Panjabrao Deshmukh Krishi Vidyapeeth, Akola. The results revealed that all the growth characters, yield attributes were significantly elevated with irrigation scheduling at 1.0 IW/CPE followed by $0.8 \mathrm{IW} / \mathrm{CPE}$. Fertilizer management with $150 \%$ RDF recorded significantly highest seed yield over rest of the combinations. Sulphur application@ $90 \mathrm{~kg} \mathrm{ha}^{-1}$ noted significant higher effect on yield contributing characters. Irrigation scheduling at $0.8 \mathrm{IW} / \mathrm{CPE}$ with $150 \%$ RDF recorded significantly highest seed yield over rest of the combinations which was at par with 1.0 IW/CPE.

\section{Introduction}

Sesame (Sesamum indicum L.) is a prehistoric oilseed crop. The crop has early origins in East Africa and in India (Bedigian, 2003). Sesame is known as the king of oil seeds due to the high oil content $(50 \%-60 \%)$ of its seed (Toan et al., 2010). Sesame oil is used as food (cooking and salad), medicine and soap manufacturing etc. Its seeds and young leaves are eaten as stews and soaps in Asia (Pakissan.com, 2010). Its oil-cake is good feed for poultry, goat, sheep, fish and cattle (Khan et al., 2009).

In India, during 2013-14, sesame was cultivated on 16.67 lakh ha area with annual production of 6.75 lakh tons. Its average productivity $\left(405 \mathrm{~kg} \mathrm{ha}^{-1}\right.$ ) is below than that of the world (535 kg ha-1), whereas, Maharashtra produced 0.70 lakh tons sesame from an area of 0.25 lakh hectare with the average productivity of $280 \mathrm{~kg} \mathrm{ha}{ }^{-1}$ (Annonimous, 2014).

Sesame has fewer problems of pest and diseases in summer condition; it can be very well harvested. Due to low input required and high price of produce of Sesame, the crop is decidedly preferred by farmers. Hence, to realize its yield potential, its agronomic parameters need to be standardized region 
wise. Irrigation, nutrient and seed rate are the key factors for boosting the yield, quality and economics of summer sesame. Therefore, the present investigation was undertaken to evaluate the impact of irrigation and nutrient levels on growth, yield and economics of Summer Sesame in Vidarbha region

\section{Materials and Methods}

A two year field experiment was conducted on sesame variety AKT 101 at University Department of Agronomy Farm, Dr. Panjabrao Deshmukh Krishi Vidyapeeth, Akola during summer season of 2012 and 2013. Experimental soil was clay loam in texture and slightly alkaline in reaction $(\mathrm{pH}$ 8.06), however, it was good for EC (0.37). It was analyzed low in available nitrogen $\left(223.72 \mathrm{~kg} \mathrm{ha}^{-1}\right)$, medium in organic carbon $(0.46 \%)$, medium in available phosphorus (16.92 $\mathrm{kg} \mathrm{ha}^{-1}$ ) and high in available potassium (394.13 $\mathrm{kg} \mathrm{ha}^{-1}$ ). The experiment was laid out in split plot design with three replications. The treatments consisted of three moisture regimes $(0.6,0.8$ and $1.0 \mathrm{IW} / \mathrm{CPE})$ and three fertilizer levels viz. 50\% RDF (12.5:12.5:0 kg NPK ha ${ }^{-1}$ ), 100\% RDF (25:25:0 kg NPK ha- $\mathrm{kg}^{-1}$ and 150\% RDF (37.5:37.5:0 $\mathrm{kg} \mathrm{NPK} \mathrm{ha}^{-1}$ ) were taken as main plot treatments. While two levels of sulphur (20 kg and $40 \mathrm{~kg} \mathrm{~S} \mathrm{ha}^{-1}$ ) were allotted as sub plot treatment. Fertilizers were drilled below seed in the soil as per treatment.

A half dose of $\mathrm{N}$ and full dose of $\mathrm{P}$ and $\mathrm{S}$ was applied at the time of sowing and the remaining half dose of $\mathrm{N}$ was applied in the rows at 30 days after sowing. The experimental data thus collected during the course of investigation were statistically analyzed with split plot design programmed on computer by adopting statistical techniques of analysis of variance (Gomez and Gomez, 1984). The net plot is converted in to quintal per hectare by using hectare factor.

\section{Results and Discussion}

\section{Growth attributes}

Pooled data exhibited in Table 1, remarked that all yield contributing characters under study were significantly influenced due to irrigation levels. Increasing trend was observed in all growth parameters as irrigation level increases. Irrigation scheduling at 1.0 IW/CPE ratio recorded significantly highest values for plant height $(98.54 \mathrm{~cm})$, leaves plant ${ }^{-1}(65.63)$, branches plant $^{-1}(4.31)$ and dry matter production plant ${ }^{1}$ (32.72 g) over irrigation scheduling at 0.8 and $0.6 \mathrm{IW} / \mathrm{CPE}$ ratio. Building of tissues, carrying of biochemical and physiological activities within the plant body to express itself, water is dominantly essential. Hence, maintaining optimum soil water regime in all the physiological stages might be the reason for manifestation of higher growth and dry matter production. Similar results were perceived by Kashved et al., (2010), Tripathy and Bastia, (2012) and Damadar et al., (2015).

Significant effects of different RDF doses were observed on growth contributing characters. The growth parameters showed an increasing trend with increasing IW/CPE ratio from 0.6 to 1.0. Application of $150 \% \mathrm{RDF}$ obtained significantly highest plant height $(97.79 \mathrm{~cm})$, number of leaves plant ${ }^{-1}(61.11)$, number of branches plant ${ }^{-1}$ (4.06) and dry matter production plant $^{-1}(26.84 \mathrm{~g})$ over 100 and $50 \%$ RDF.

This may happen due to the availability of every nutrient in sufficient quantity which created the favorable situation for physiological processes, metabolic activities and nutrient uptake, have a positive effect on formation of new cells, optimum cell division and stem elongation. These results are in conformity with findings of Sarkar et al., 
(2010), Damdar et al., (2015) and Jadhav et al., (2015). Growth attributes were not significantly affected due to sulphur levels, whereas, higher values were recorded with the application of sulphur $40 \mathrm{~kg} \mathrm{ha}^{-1}$. Significant Interaction effect between irrigation scheduling at 1.0 IW/CPE ratio and fertilizer dose with $150 \%$ was found than any other combination.

\section{Yield attributes}

Data on yield attributes in Table 2 revealed that irrigation scheduling at $1.0 \mathrm{IW} / \mathrm{CPE}$ ratio recorded significantly maximum number of capsules plant $^{-1}$, test weight and seed yield plant $^{-1}$ than 0.6 IW/CPE ratio was being at par with $0.8 \mathrm{IW} / \mathrm{CPE}$ ratio. The increase in yield attributes might be due favorable plant water balance maintained through proper irrigation scheduling resulted in better maintenance of cell turgidity, consequently leading to better growth and beneficial effect on translocation of photosynthates toward sink viz., flowering, better capsule setting and seed filling. These results are in agreement with those obtained by Tripathy and Bastia (2012) and Damadar et al., (2015).

Table.1 Growth parameters, yields attributes and yield of summer Sesame as influenced by irrigation scheduling, nutrient and sulphur levels (Pooled)

\begin{tabular}{|c|c|c|c|c|c|c|c|c|c|}
\hline Treatments & $\begin{array}{c}\text { Plant } \\
\text { height } \\
\text { (cm) }\end{array}$ & $\begin{array}{l}\text { Leaves } \\
\text { plant }^{-1}\end{array}$ & $\begin{array}{c}\text { Branches } \\
\text { plant }^{-1}\end{array}$ & $\begin{array}{c}\text { Dry } \\
\text { matter } \\
\text { plant }^{-1} \\
(\mathrm{~g})\end{array}$ & $\begin{array}{c}\text { Capsules } \\
\text { plant }^{-1}\end{array}$ & $\begin{array}{c}\text { Test } \\
\text { weight } \\
\text { (g) }\end{array}$ & $\begin{array}{c}\text { Seed } \\
\text { yield } \\
\text { plant }^{-1} \\
(\mathrm{~g})\end{array}$ & $\begin{array}{c}\text { Seed } \\
\text { yield } \\
\left(\mathbf{q} \mathbf{h a}^{-1}\right)\end{array}$ & $\begin{array}{c}\text { Stalk } \\
\text { yield } \\
\left(\mathbf{q} \mathbf{h a}^{-1}\right)\end{array}$ \\
\hline \multicolumn{10}{|l|}{ Main Plot } \\
\hline \multicolumn{10}{|c|}{ A) Irrigation Scheduling } \\
\hline $\mathrm{I}_{1}-0.6 \mathrm{IW} / \mathrm{CPE}$ & 81.03 & 44.84 & 2.87 & 13.52 & 34.95 & 1.96 & 1.62 & 4.19 & 39.94 \\
\hline $\mathrm{I}_{2}-0.8 \mathrm{IW} / \mathrm{CPE}$ & 93.04 & 55.33 & 3.24 & 18.57 & 54.12 & 2.32 & 2.32 & 5.62 & 59.39 \\
\hline $\mathrm{I}_{3}-1.0 \mathrm{IW} / \mathrm{CPE}$ & 98.54 & 65.63 & 4.31 & 32.72 & 55.72 & 2.57 & 2.40 & 5.64 & 82.13 \\
\hline $\mathrm{SE}(\mathrm{m}) \pm$ & 1.15 & 1.21 & 0.08 & 0.44 & 0.936 & 0.064 & 0.045 & 0.097 & 2.421 \\
\hline CD@5\% & 3.43 & 3.64 & 0.23 & 1.31 & 2.805 & 0.191 & 0.135 & 0.292 & 7.256 \\
\hline \multicolumn{10}{|c|}{ B) $\quad$ Fertilizer management } \\
\hline $\mathrm{F}_{1}-50 \% \mathrm{RDF}$ & 84.65 & 47.85 & 2.81 & 16.47 & 38.58 & 1.86 & 1.64 & 4.08 & 40.47 \\
\hline $\mathrm{F}_{2}-100 \% \mathrm{RDF}$ & 90.16 & 56.84 & 3.54 & 21.50 & 46.62 & 2.16 & 2.13 & 5.14 & 55.00 \\
\hline $\mathrm{F}_{3}-150 \% \mathrm{RDF}$ & 97.79 & 61.11 & 4.06 & 26.84 & 59.59 & 2.82 & 2.56 & 6.22 & 86.00 \\
\hline $\mathrm{SE}(\mathrm{m}) \pm$ & 1.15 & 1.21 & 0.08 & 0.44 & 0.936 & 0.064 & 0.045 & 0.097 & 2.421 \\
\hline CD@5\% & 3.43 & 3.64 & 0.23 & 1.31 & 2.805 & 0.191 & 0.135 & 0.292 & 7.256 \\
\hline \multicolumn{10}{|l|}{ Sub Plot } \\
\hline \multicolumn{10}{|c|}{ C) $\quad$ Sulphur levels } \\
\hline $\mathrm{S}_{1}-20 \mathrm{~kg} \mathrm{~S} \mathrm{ha}^{-1}$ & 90.45 & 54.94 & 3.38 & 21.12 & 46.93 & 2.16 & 2.07 & 5.07 & 59.28 \\
\hline $\mathrm{S}_{2}-40 \mathrm{~kg} \mathrm{~S} \mathrm{ha}^{-1}$ & 91.29 & 55.60 & 3.56 & 22.09 & 49.60 & 2.41 & 2.15 & 5.23 & 61.70 \\
\hline $\mathrm{SE}(\mathrm{m}) \pm$ & 0.73 & 0.91 & 0.07 & 0.34 & 0.532 & 0.053 & 0.022 & 0.048 & 1.460 \\
\hline CD@5\% & NS & $\mathrm{NS}$ & NS & NS & 1.579 & 0.158 & 0.064 & 0.143 & NS \\
\hline C.V. \% & 5.35 & 9.32 & 9.46 & 8.57 & 8.22 & 11.83 & 9.03 & 8.02 & 16.97 \\
\hline \multicolumn{10}{|c|}{ Interactions } \\
\hline \multicolumn{10}{|c|}{ Irrigation x Fertilizer $(\mathbf{A x B})$} \\
\hline $\mathrm{SE}(\mathrm{m}) \pm$ & 1.98 & 2.10 & 0.13 & 0.76 & 1.62 & 0.11 & 0.08 & 0.17 & 4.19 \\
\hline CD@5\% & 4.36 & 6.30 & 0.40 & 2.26 & 4.85 & NS & 0.23 & 0.51 & 12.57 \\
\hline \multicolumn{10}{|c|}{ Irrigation x Sulphur $(\mathbf{A x C})$} \\
\hline $\mathrm{SE}(\mathrm{m}) \pm$ & 1.26 & 1.58 & 0.128 & 0.59 & 0.92 & 0.09 & 0.04 & 0.08 & 2.53 \\
\hline CD @ $5 \%$ & NS & NS & $\mathrm{NS}$ & NS & $\mathrm{NS}$ & $\mathrm{NS}$ & $\mathrm{NS}$ & $\mathrm{NS}$ & $\mathrm{NS}$ \\
\hline \multicolumn{10}{|c|}{ Fertilizer x Sulphur $(\mathbf{B x C})$} \\
\hline $\mathrm{SE}(\mathrm{m}) \pm$ & 1.09 & 1.37 & 0.11 & 0.51 & 0.79 & 0.08 & 0.03 & 0.07 & 2.19 \\
\hline CD @5\% & NS & NS & $\mathrm{NS}$ & NS & $\mathrm{NS}$ & $\mathrm{NS}$ & $\mathrm{NS}$ & $\mathrm{NS}$ & $\mathrm{NS}$ \\
\hline C.V.\% & 4.17 & 8.55 & 11.09 & 8.19 & 5.72 & 12.09 & 5.29 & 4.86 & 12.54 \\
\hline
\end{tabular}


Table.2 Interaction effect of irrigation and RDF levels on seed yield ( $q \mathrm{ha}^{-1}$ ) of summer sesame (Pooled)

\begin{tabular}{|l|c|c|c|}
\hline \multirow{2}{*}{ Irrigation Levels } & \multicolumn{3}{|c|}{ RDF Levels } \\
\cline { 2 - 4 } & $\mathbf{F}_{\mathbf{1}}(50 \% \mathrm{RDF})$ & $\mathbf{F}_{\mathbf{2}}(100 \% \mathrm{RDF})$ & $\mathbf{F}_{\mathbf{3}}(150 \% \mathrm{RDF})$ \\
\hline $\mathbf{I}_{\mathbf{1}}-0.6 \mathrm{IW} / \mathrm{CPE}$ & 3.70 & 4.00 & 4.87 \\
\hline $\mathbf{I}_{\mathbf{2}}-0.8 \mathrm{IW} / \mathrm{CPE}$ & 4.10 & 5.77 & 7.00 \\
\hline $\mathbf{I}_{\mathbf{3}}-1.0 \mathrm{IW} / \mathrm{CPE}$ & 4.45 & 5.66 & 6.80 \\
\hline SE(m) $\mathbf{\pm}$ & \multicolumn{3}{|}{0.17} \\
\hline CD $@ \mathbf{5 \%}$ & \multicolumn{3}{|c|}{0.51} \\
\hline
\end{tabular}

Fig.1 Effect of irrigation, RDF and sulphur levels on seed yield $\left(\mathrm{q} \mathrm{ha}^{-1}\right)$ of summer sesame

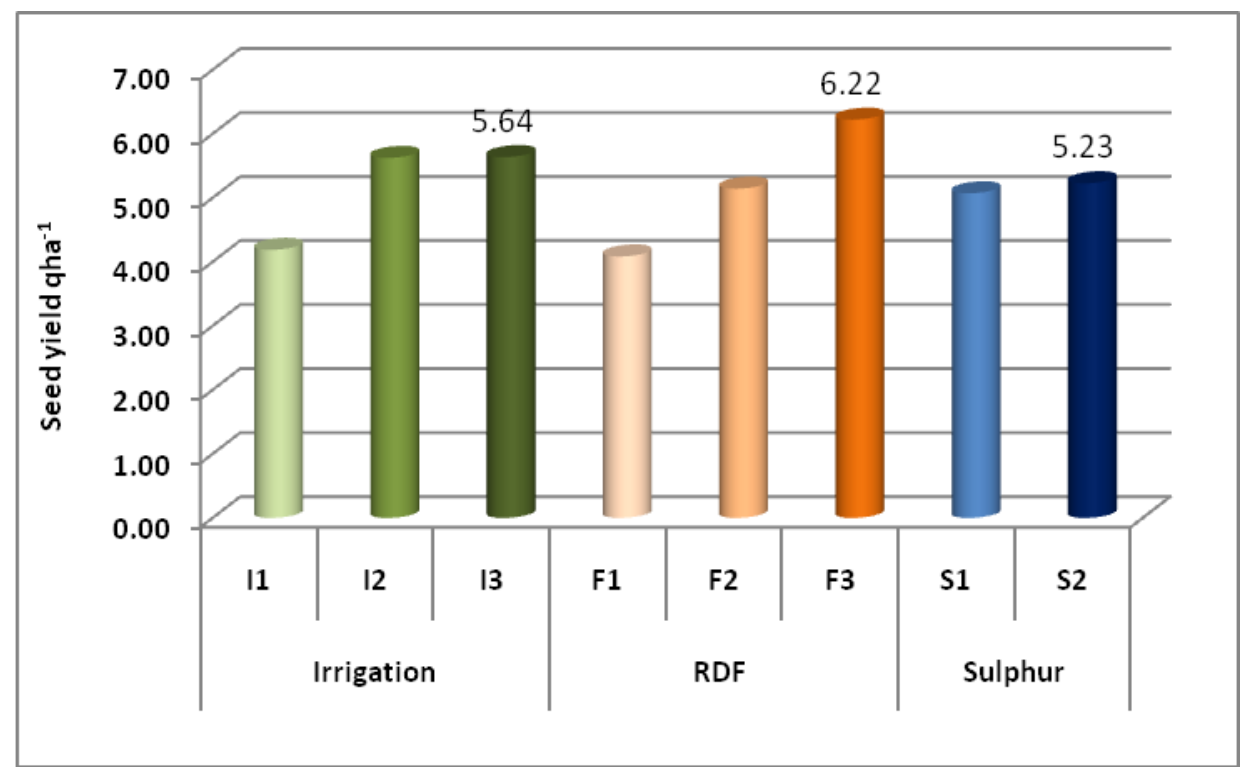

Number of capsules plant ${ }^{-1}$, test weight and seed yield plant ${ }^{-1}$ were significantly increased as the RDF doses increased as 50, 100 and $150 \%$. Application of $150 \%$ RDF recorded significantly highest values for all yield attributes under study. This might be due to availability of sufficient quantity of nutrients when required which resulted in encouraged flowering, better capsule setting and seed filling. Damdar et al., (2015) observed identical trend due to nitrogen application alone.

Significant effect of sulphur was recorded on yield attributes. Application of sulphur @ 40 $\mathrm{kg} \mathrm{ha}^{-1}$ recorded significantly higher number of capsules plant ${ }^{-1}(49.60)$, test weight $(2.41 \mathrm{~g})$ and seed yield plant ${ }^{-1}(2.15 \mathrm{~g})$ than $20 \mathrm{~kg} \mathrm{ha}^{-1}$. Sonia Shilpi et al., (2012) reported the same results with application of sulphur @ $40 \mathrm{~kg}$ $\mathrm{ha}^{-1}$ than 20 and $0 \mathrm{~kg} \mathrm{ha}^{-1}$.

\section{Yield studies}

Irrigation, RDF and sulphur levels showed significant effect on seed and stalk yield of summer sesame var. AKT-101 (Fig. 1). Significantly highest seed yield $\left(5.64 \mathrm{q} \mathrm{ha}^{-1}\right)$ was obtained with irrigation at $1.0 \mathrm{IW} / \mathrm{CPE}$ ratio which was $34.61 \%$ greater than at 0.6 IW/CPE ratio, but found at par when applied at $0.8 \mathrm{IW} / \mathrm{CPE}$ ratio, whereas, stalk yield was 
significantly increased with increase in irrigation levels. Highest stalk yield (82.13 q $\mathrm{ha}^{-1}$ ) was observed with irrigation at 1.0 IW/CPE ratio which was near about double than yield obtained (39.94 q ha ${ }^{-1}$ ) from irrigation at $0.6 \mathrm{IW} / \mathrm{CPE}$ ratio. This might be due to increase in the yield contributing attributes and dry matter production, as the plant gets required quantity of water at 1.0 IW/CPE ratio. These results are in agreement with those of Damdar et al., (2015) and Jadhav et al., (2015).

Linear increasing trend was observed in seed and stalk yield of sesame due to increase in RDF dose from 50 to $150 \%$. Significantly highest seed $\left(6.22 \mathrm{q} \mathrm{ha}^{-1}\right)$ and stalk $(86.00 \mathrm{q}$ $\mathrm{ha}^{-1}$ ) yield were noted with $150 \%$ RDF which were $52.29 \%$ and $112.48 \%$ more, respectively, than the seed $\left(4.08 \mathrm{q} \mathrm{ha}^{-1}\right)$ and stalk (40.47 $\mathrm{q} \mathrm{ha}^{-1}$ ) yield with $50 \%$ RDF. It might happen due to the better response of yield attributes to the increasing fertilizer levels. The same results in case of oil yield of sesame were reported by Jadhav et al., (2015), whereas, Prasanna kumara et al., (2014), recorded negative response of sesame to increasing fertilizer levels in terms of seed and stalk yield. Higher dose of sulphur i.e. 40 $\mathrm{kg} \mathrm{ha}{ }^{-1}$ significantly increase the seed yield by $3.09 \%$ than the lower dose of $20 \mathrm{~kg} \mathrm{ha}^{-1}$. Supply of $\mathrm{S}$ in addition to N, P and $\mathrm{K}$ had positive effect on the yield attributes as it increases the oil content of seed and therefore, finally increased the seed yield. These findings are in accordance with the earlier reports of Raja et al., (2007) and Sonia Shilpi et al., (2012). The stalk yield was not significantly influenced due to sulphur application.

\section{Interaction effect of irrigation and RDF levels}

Irrigation and RDF levels interacted significantly in respect of seed yield of sesame (Table 2). Irrigation at $0.8 \mathrm{IW} / \mathrm{CPE}$ ratio with $150 \% \mathrm{RDF}\left(\mathrm{I}_{2} \times \mathrm{F}_{3}\right)$ combination recorded significantly higher seed yield (7.00 $\mathrm{q} \mathrm{ha}^{-1}$ ) than all other combinations. However, it was found at par with irrigation at 1.0 IW/CPE with same level of $\mathrm{RDF}\left(\mathrm{I}_{3} \times \mathrm{F}_{3}\right)$ which yielded $6.80 \mathrm{q} \mathrm{ha}^{-1}$. The increase in seed yield with the interaction between irrigation and RDF levels, might be due to the availability of water and $\mathrm{N}$ and $\mathrm{P}$ provides optimum ground for plant vegetative growth and increases photosynthesis area, assimilate production, number of capsules plant ${ }^{-1}$ and number of seeds capsule ${ }^{-1}$ and finally, significantly increases seed yield. These results are in line with the findings of Damdar et al., (2015) and Jadhav et al., (2015).

It can be concluded from the present study that the maximum seed yield ( $\left.7.00 \mathrm{q} \mathrm{ha}^{-1}\right)$ was harvested with irrigation schedule at 0.8 IW/CPE ratio in combination with application of $150 \% \operatorname{RDF}\left(37.5: 37.5: 0 \mathrm{~kg} \mathrm{NPK} \mathrm{ha}{ }^{-1}\right)$.

\section{References}

Anonymous, 2014. Status Paper on Oilseeds, Oilseeds Division, Department of Agriculture and Cooperation, Ministry of Agriculture, Govt. of India, December, 2014.

Bedigian D., 2003. Evolution of sesame revisited: domestication, diversity and prospects. Genet Resour Crop Evol. 50: 779-787.

Damdar Rupali R., V.M. Bhale and K.M. Deshmukh (2015), Yield, Growth and Quality of summer sesame (Sesamum indicum L.) as influenced by irrigation and nitrogen levels, International Journal of Agricultural Sciences, 11(2), 301-306.

Gomez, K.A., Gomez A.A., 1984. Statistical Procedure for Agricultural Research. John Viley and Sons, New York. Pp. 680. 
Jadhav S.R., M.D. Naiknaware and G.R. Pawar, (2015), Effect of Nitrogen, Phosphorous and Biofertillizres on Growth, Yield and Quality of Summer Sesamum (Sesamum indicum L.), International Journal of Tropical Agriculture, 33(2), 475-480.

Khan, M.H.A., Sultana, N.A., Islam, M.N. and Zaman, M.H. (2009) Yield and Yield Contributing Characters of Sesame as Affected by Different Management Practices. AmericanEurasian Journal of Scientific Research, 4, 195-197.

Pakissan.com (2010) Sesame Production Practices in Pakistan. http://www.pakissan.com/english/allabo ut/ crop/sesame.shtml

Prasanna kumara H., B.M. Chittapur, S. M. Hiremath, L.H. Malligwad, H.L. Nadaf and R.V. Koti. (2014). Effect of fertilizer levels and planting geometry on the performance of sesame (Sesamum indicum L.). Genotypes. Karnataka J. Agric. Sci., 27 (3): 289292.

Raja, K. Omar Hattab, L. Gurusamy, G.
Vembu and S. Suganya. (2007). Sulphur Application on Growth and Yield and Quality of Sesame Varieties. Int. J. Agri. Res., 2 (7): 599-606.

Sarkar, A., S. Sarkar A. Zaman and S.K. Rana, 2010.Performance of summer sesame (Sesamum indicum L.) under different irrigation regimes and nitrogen levels. Indian J. Agron., 55(2): 143-146.

Sonia Shilpi, M. N. Islam, G. N. C. Sutradhar, AsmaulHusna and Fahmina Akter. (2012), Effect of Nitrogen and Sulfur on the Growth and Yield of Sesame. International Journal of Bio-resource and Stress Management, 3(2):177-182

Toan, D.P., Thuy-Duong, T.N.A., Carlsson, S. and T.M. Bui, (2010) Morphological Evaluation of Sesame (Sesamum indicum L.) Varieties from Different Origins. Australian Journal of Crop Science, 4, 498-504.

Tripathy, S., and D. K. Bastia. 2012. Irrigation and nutrient management for yield augmentation of summer sesame (Sesamum indicum L.). J. Crop and Weed, 8(2): 53-57

\section{How to cite this article:}

Khadse, V.A., P.U. Ghatol and Bhale, V.M. 2017. Performance of Summer Sesame under different Irrigation Scheduling and Nutrient Levels in Vidarbha Region. Int.J.Curr.Microbiol.App.Sci. 6(11): 1988-1993. doi: https://doi.org/10.20546/ijcmas.2017.611.236 